\title{
Association Between Fomesafen and Surfactants for the Pre-emergence Control of Euphorbia heterophylla L.
}

\author{
Matheus Viecelli, Michelangelo Muzzel Trezzi, Fortunato De Bortolli Pagnoncelli Jr, Bruna \\ Mandryk Cavalheiro, Renata Caroline Rossoni Gobetti, José Ricardo da Rocha Campos, \\ Felipe Machado, Matheus Tonatto
}

Federal University of Technology - Parana (UTFPR), Brazil

Received: Aug. 16, 2020

doi:10.5296/jas.v8i4.17582
Accepted: Sep. 17, $2020 \quad$ Published: Sep. 24, 2020

URL: https://doi.org/10.5296/jas.v8i4.17582

\begin{abstract}
This work was conducted with the objective to determine Euphorbia heterophylla control with fomesafen in association with surfactants applied in pre-emergence, in substrates and soils with different characteristics. Three studies were carried out in pots, conducted in greenhouse, in a completely randomized experimental design. The first two studies consisted of investigating the efficacy of pre-emergence combinations of fomesafen and surfactant in the control of $E$. heterophylla, applied on different substrates (Study 1) and soils (Study 2) with different textural classes. Study 3 was carried out to evaluate the effect of fomesafen, applied in pre-emergence and in combination with adjuvants with different HLB's (hydrophilic-lipophilic balances). The herbicide efficacy on E. heterophylla and plant shoot dry mass were evaluated. The association of adjuvant to fomesafen, in pre-emergence, reduced plant growth in the different substrates and soils. The fomesafen response was influenced by the addition of surfactants with different HLB's. The increase in organic matter content in substrates or soil was related to the decrease of the effect of the surfactants on the control of E. heterophylla with fomesafen, or the effect was only manifested in higher herbicide dosages. Fomesafen associated with surfactant with HLB of 8.6 provided the highest levels of weed control.
\end{abstract}

Keywords: wild poinsettia, herbicide, surfactant, substrate, soil, hydrophilic-lipophilic balance

\section{Introduction}

The species Euphorbia heterophylla, commonly known as wild poinsettia, is a widely disseminated dicotyledon weed in Brazil, which has a high competitive ability with crop plants (Voll et al., 2002). Herbicides from several mechanisms of action are used to control $E$. heterophylla. The herbicide fomesafen [5-[2-chloro-4-(trifluoromethyl) phenoxy]-N-(methylsulfonyl)-2-nitrobenzamide], is a diphenylethers, and inhibits the plant 
enzyme protoporphyrinogen oxidase (PPO) (Senseman, 2007). Fomesafen is an important compound for the management of E. heterophylla and other dicotyledon species. In soybean and bean crops, this herbicide is used for the early post-emergence control of broad-leaved weeds, such as wild poinsettia (E. heterophylla), pigweed (Amaranthus deflexus, A. viridis, A. hydridus), morning glory (Ipomoea aristolochiifolia, I. purpurea), hairy beggarticks (Bidens pilosa), among others (BRASIL, 2019).

Adjuvants are commonly used to increase the herbicide control efficacy over weeds. Adjuvants are defined as products added to the mixing tank to aid or modify the action of pesticides or the physical characteristics of the mixture (Azevedo, 2007). Therefore, the use of adjuvants aims to facilitate the absorption of the pesticide by the plant, to increase the efficacy of the compound, or to reduce the risks of pesticide use. In practice, the use of adjuvants is carried out to improve wetting, spreading and penetration of the active ingredient into the biological target (Azevedo, 2011). In a general definition, surfactants are agricultural adjuvants classified according to their function, in this case as leaf surface active agents.

To facilitate foliar absorption of fomesafen by plants, it is recommended its association with the mixture of nonylphenoxypoly (ethyleneoxy) etanol (22.6\%) and sodium salt of dodecyl benzene sulfonic acid (22.6\%) (Energic $^{\circledR}$, registered trademark of Syngenta Crop Protection) (BRASIL, 2019). It's not usual to recommend surfactants for herbicide applications in pre-emergence, because in this modality supposedly would not increase wetting, spreading and penetration of herbicides in plants. However, several studies report the interference of surfactants on the mobility of herbicides in soil (Werkheise \& Andreson, 1996; Locke et al., 2002; Kucharsky, 2007; Hua et al., 2009; Hussein \& Ballah, 2016), which may interfere in the control efficacy.

Both the herbicide and the adjuvant, when applied to the soil, may have a physical-chemical action, which regulates its dynamics in the environment. The dynamic of pesticides in the soil depends on processes such as adsorption and desorption, which are related to the pesticide and soil characteristics. The retention of the pesticide interferes in other processes, such as leaching, volatilization, photodegradation, chemical and biological decomposition, surface runoff and plant action (Brighenti \& Oliveira 2011).

Pesticide physical-chemical characteristics which affects its behavior in the soil include acid dissociation constant $\left(\mathrm{pk}_{\mathrm{a}}\right)$, octanol-water partition coefficient $\left(\mathrm{K}_{\mathrm{ow}}\right)$, and water solubility. Fomesafen is a weak acid with $\mathrm{pk}_{\mathrm{a}}$ of 2.7 at $20^{\circ} \mathrm{C}$, has medium lipophilicity with $\mathrm{K}_{\text {ow }}$ of 794 (pH 1.0) and it has water solubility of $600 \mathrm{~g} / \mathrm{L}$ (sodium salt) at $25^{\circ} \mathrm{C}$ (Senseman 2007). Adjuvants characteristics that affect pesticide dynamics in the soil include the electrostatic dissociation capacity and the hydrophilic-lipophilic balance (HLB) (Brighenti \& Oliveira 2011). Therefore, interrelations of physical-chemical factors of the herbicide molecule and the surfactant, combined with biotic and abiotic factors of the environment, interfere with the herbicide activity in the soil and, consequently, its action in the plant. It is important to investigate different herbicide-surfactant combinations in different substrates or soils to understand of the mechanisms involved on pesticide behavior in the soil and to improve the weed management and control.

The adsorption of fomesafen responds linearly to the soil organic matter content (Senseman, 
2007) and other texture attributes (Silva et al., 2013; Karpinski et al., 2014). Thus, it is important to investigate whether soil with different organic matter contents may impact the efficacy of fomesafen on the control of E. heterophylla. Considering that the use of surfactants in the soil can interfere with soil herbicide dynamics, it's also important to investigate whether the action of fomesafen, when applied in pre-emergence of $E$. heterophylla, can be maximized with the addition of surfactant, and if this effect is influenced by organic matter content and soil texture attributes. It is hypothesized that a variation in the hydrophilic-lipophilic balance (HLB) of the surfactants affects the interaction of fomesafen with the soil and, therefore, its impact on E. heterophylla when the herbicide is applied in pre-emergence. The objective of this work was to determine the efficacy of fomesafen on Euphorbia heterophylla control when associated with different surfactant concentrations and surfactant HLB's, applied in pre-emergence, on different textural compositions of soils.

\section{Method}

Three greenhouse experiments were conducted. The greenhouse was located in Pato Branco, state of Paraná, Brazil (latitude $26^{\circ} 11^{\prime} \mathrm{S}$ and longitude $52^{\circ} 41^{\prime} \mathrm{W}$ ). Experiment 1 have evaluated the effect of surfactant associated with fomesafen when applied in pre-emergence in substrates with different proportions of soil and sand. In experiment 2 the substrate consisted of different soil types. Experiment 3 have assessed the effect of surfactants with different hydrophilic-lipophilic balances (HLB's) associated with fomesafen sprayed in pre-emergence for weed control.

In all experiments, the herbicide was fomesafen, which was associated to surfactant (s) and sprayed in pre-emergence of plants. The experimental design was completely randomized, and the experimental units were pots with $3 \mathrm{dm}^{3}$ capacity. The chemicals were applied with a back-pack sprayer, pressurized with $\mathrm{CO}_{2}$ at a constant pressure of $330 \mathrm{kPa}$. This equipment had four spray nozzles, type XR.110.02, spaced $0.5 \mathrm{~m}$ apart, and was adjusted to deliver a spray volume of $200 \mathrm{~L} \mathrm{ha}^{-1}$.

In all experiments, the reagent weed species was E. heterophylla using eight seeds per pot. In studies 1 and 2, it was used a biotype with multiple herbicide resistance (R) to inhibitors of the enzymes protoporphyrinogen oxidase (PPO) and acetolactate synthase (ALS), whereas in Study 3 a susceptible (S) biotype. The aim of using susceptible E. heterophylla in studies 1 and 2 was to avoid surfactant's response was overlapped by high herbicide effectiveness. Therefore, in study 3 was used the susceptible biotype to ensure that the effect of HLB was expressed, since the response in resistant biotype could have not been visualized. Also, to assist in this matter the doses have also been reduced. Seeds from both populations were attained at the germplasm bank of UTFPR - Pato Branco Campus. Seeds from the R biotype originally was collected in a farms located in the city of Vitorino (PR) (Trezzi et al., 2009; Trezzi et al., 2011; Xavier et al., 2013), whereas the seeds from the S biotype was purchased originally from the company Cosmos Agrícola Ltda, from São Paulo. The soils used in the experiments were dried in the shade, periodically revolved and subsequently sieved. The sand used was initially washed with flowing water and then dried in the shade.

In all experiments, eight seeds of $E$. heterophylla were sown per pot pot and the germination index 
in R and S biotype was 78 and 63\%, respectively. During the conduction of the studies, manual removal of weeds (with the exception of E. heterophylla) was done daily and the soil was irrigated to keep its moisture content at the field capacity. Every seven days, nutrients were added to the soil using a solution of $20 \mathrm{~mL}$ per pot of 50\% Hoagland solution (Hoagland \& Arnon 1950).

\subsection{Study 1 - Association Between Fomesafen and Adjuvant Sprayed in Pre-Emergence of E.} Heterophylla in Different Soil/Sand Ratios

The treatments were arranged as a three-factorial $(4 \times 4 \times 3)$ with three replicates. The first factor consisted of different soil/sand proportions $(0 / 100 \%, 33 / 66 \%, 66 / 33 \%$ and 100/0\%). The second factor was assigned to four doses of fomesafen $\left(0,125,250\right.$ and $\left.500 \mathrm{~g} \mathrm{ha}^{-1}\right)$, (Flex ${ }^{\circledR}$, Syngenta Crop Protection). The third factor consisted of three concentrations $(0 \%$, $0.2 \%$ and $1 \% \mathrm{v} / \mathrm{v}$ ) of surfactant Energic ${ }^{\circledR}$ (composed of $22.6 \%$ ethyleneoxy ethanol and $22.6 \%$ sodium salt of dodecyl benzene sulphonic acid). It's important to emphasize that, according to information from Syngenta Crop Protection, the fomesafen $\left(\mathrm{Flex}^{\circledR}\right.$ ) formulation commercialized in Brazil does not contain any type of surfactant.

The four soil/sand ratios were obtained by mixing these components with the aid of concrete mixer. The textural composition and chemical characteristics of the four proportions are described in Table 1. An untreated control (absence of herbicide and surfactants) treatment was used for comparisons with the other treatments.

Table 1. Textural composition and chemical characteristics of the different substrates -proportions soil/sand: $100 \%, 66 \% 33 \%$ and $0 \%$ soil

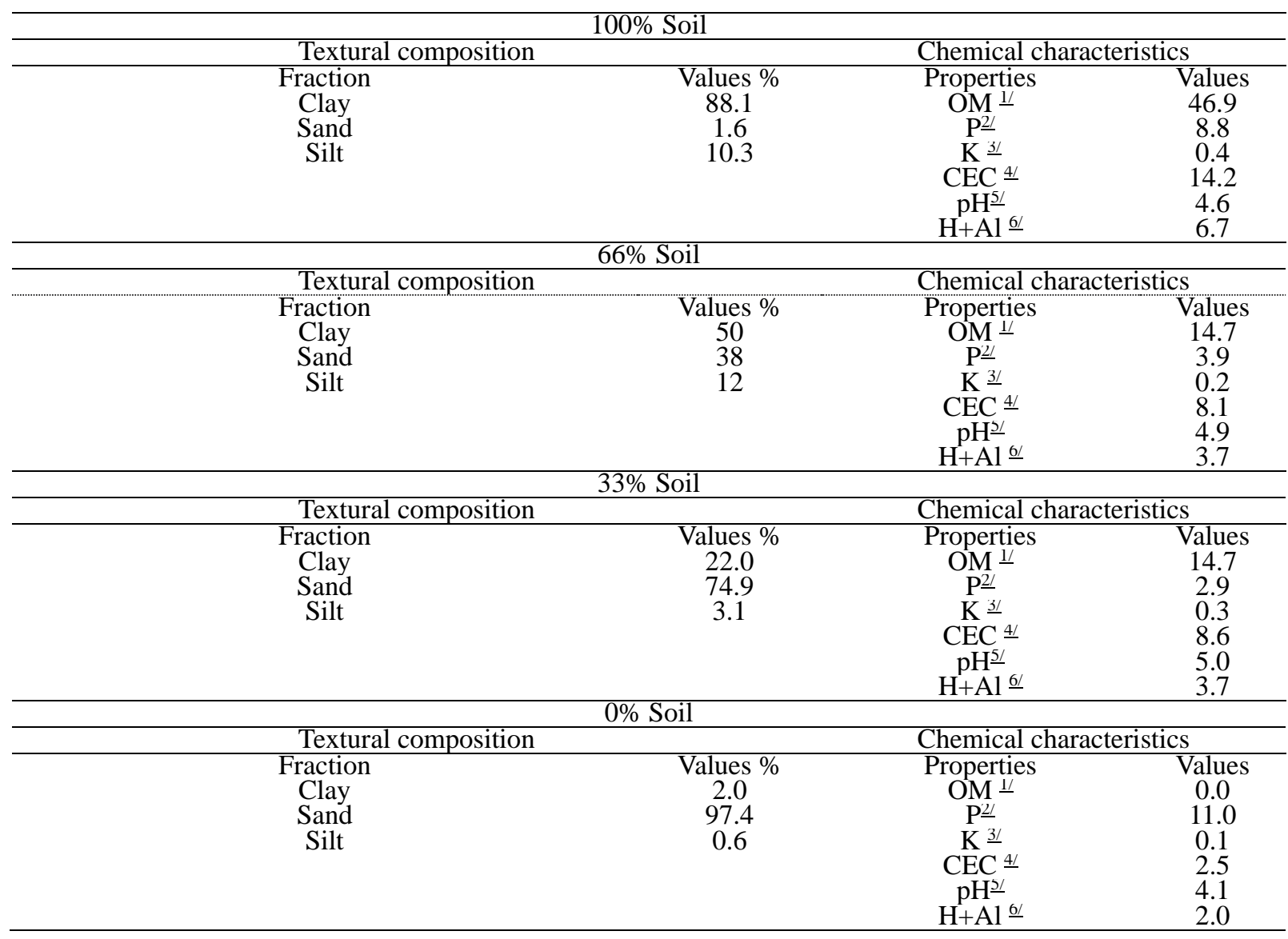


${ }^{*} 1 /$ Organic matter $\left(\mathrm{g} \mathrm{dm}^{-3}\right) ;{ }^{2 /}$ Phosphorus $\left(\mathrm{mg} \mathrm{dm}^{-3}\right) ;{ }^{3 /}$ Potassium $\left(\mathrm{cmol}_{\mathrm{c}} \mathrm{dm}^{-3}\right) ;{ }^{4 /}$ Cation exchange capacity $\left(\mathrm{cmol}_{\mathrm{c}}\right.$ $\left.\mathrm{dm}^{-3}\right) ;{ }^{5 /} \mathrm{pH}$ of soil $\left(\mathrm{CaCl} 20,01 \mathrm{~mol} \mathrm{~L}^{-1}\right) ;{ }^{6 /}$ Exchangeable acidity $\left(\mathrm{cmol}_{\mathrm{c}} \mathrm{dm}^{-3}\right)$.

2.2 Study 2 - Association Between Fomesafen and Adjuvant Sprayed in Pre-Emergence of E. Heterophylla in Different Soils

The treatments were arranged as a three-factorial $(3 \times 4 \times 3)$ with four replicates. The factors consisted of: three soil types collected in cropping areas located in the cities of Pato Branco, Palmas (Southwest of Parana) and Irati (Mid-South of Parana), four doses of fomesafen (0, 125,250 and $\left.500 \mathrm{~g}_{\text {a.i. }} \mathrm{ha}^{-1}\right)$ and three concentrations of the Energic ${ }^{\circledR}(0 \%, 0.2 \%$ and $1 \% \mathrm{v} / \mathrm{v})$. The textural composition and chemical characteristics of soils are presented in Table 2.

Table 2. Textural composition and chemical characteristics of the soils from Pato Branco, Irati and Palmas

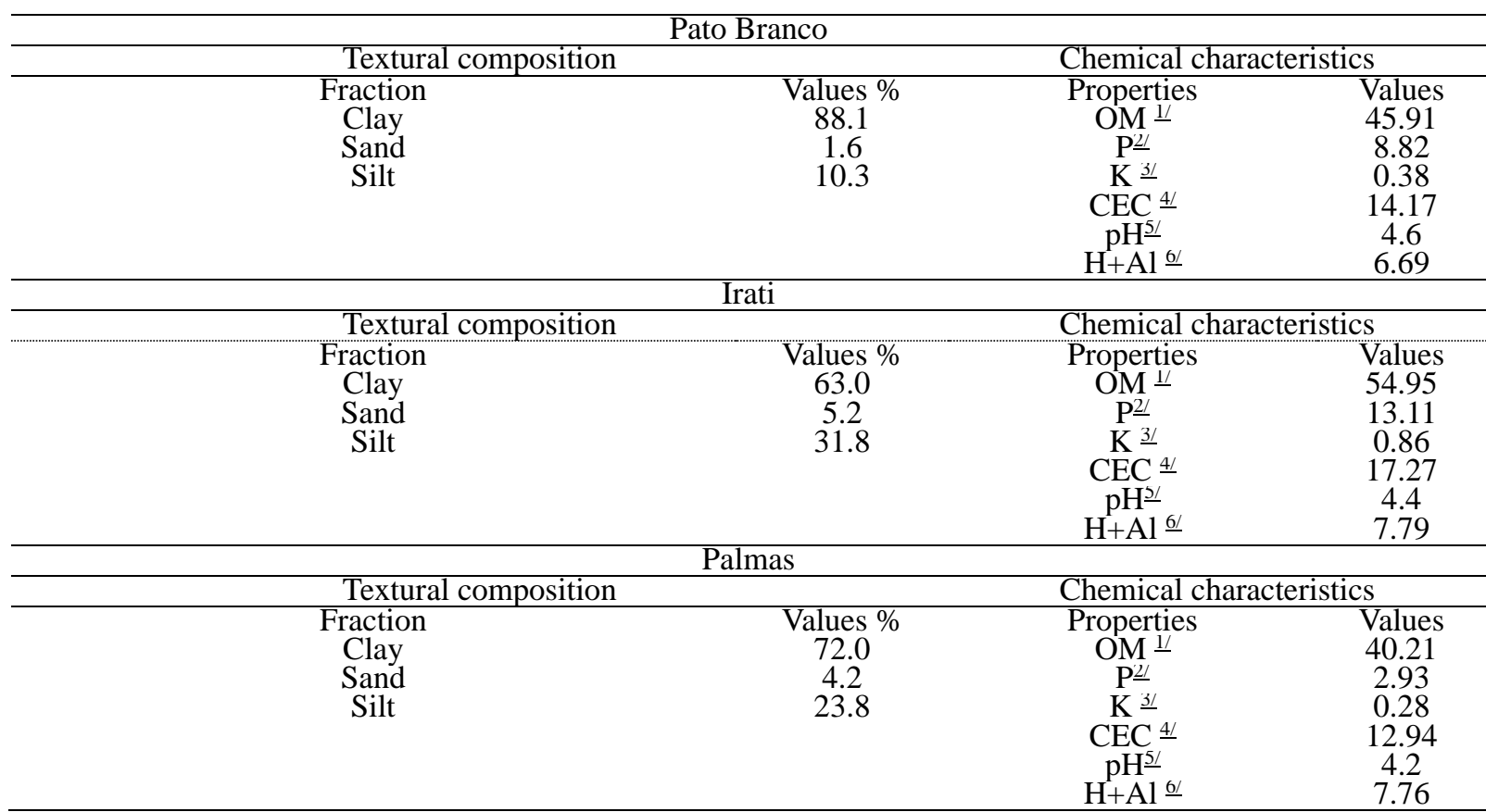

${ }^{* 1 /}$ Organic matter $\left(\mathrm{g} \mathrm{dm}^{-3}\right) ;{ }^{2 /}$ Phosphorus $\left(\mathrm{mg} \mathrm{dm}^{-3}\right) ;{ }^{3 /}$ Potassium $\left(\mathrm{cmol}_{\mathrm{c}} \mathrm{dm}^{-3}\right) ;{ }^{4 /}$ Cation exchange capacity; ${ }^{5 /} \mathrm{pH}$ of soil; ${ }^{6 /}$ Exchangeable acidity $\left(\mathrm{cmol}_{\mathrm{c}} \mathrm{dm}^{-3}\right)$.

2.3 Study 3 - Association Among Adjuvants With Distinct HLB's and the Herbicide Fomesafen When Sprayed in Pre-Emergence of E. Heterophylla

The treatments were arranged as a factorial $(3 \times 6)$ with four replicates. The factors consisted of three doses of fomesafen $\left(0,63\right.$ and $125 \mathrm{~g}$ a.i. ha $\left.{ }^{-1}\right)$ and six surfactants with different HLB's (Alkest SP80 with HLB 4.3, Alkest L20 M com HLB 8.6, 58\% Alkest L20 M + 42\% Alkest TW20 with HLB 12, Alkest TW80 with HLB 15, and Alkest TW 27 with HLB 17.8). An untreated control without surfactant application was used for comparison with the other treatments. Surfactants were provided by Oxiteno S.A.

The soil used in this experiment was the one collected in Pato Branco, whose textural composition and chemical characteristics were described in Table 1. 


\subsection{Assessments and Statistical Analysis}

Two types of evaluations were performed in all the experiments. First, assessment of herbicide efficacy on E. heterophylla control at 21 days after application (DAA). Herbicide symptoms observed on plants were assigned values between 0 and $100 \%$, where $0 \%$ corresponded to absence of perceived plant damage and $100 \%$ to plant death (Frans et al. 1986). Second, evaluation of the shoot dry mass (SDM) of E. heterophylla shoots. At 28 DAA the plants were cut at the base near the soil surface and the shoots were dried in an air circulation-oven, at $60^{\circ} \mathrm{C}$, until constant weight. The SDM data were converted to percentage in relation to the untreated control.

The data were submitted to an analysis of variance by the $\mathrm{F}$ test $((p \leq 0.05)$, using the software R, using the ExpDes.pt Package (Ferreira et al. 2013). The means of the analyzed variables were used to adjust nonlinear regressions with error probability of $5 \%$ for the equation parameters. For the comparison of the effects of treatments, the mean standard error $(\sigma / \sqrt{ } \mathrm{n})$ was used, where: $\sigma=$ sample standard deviation and $\mathrm{n}=$ number of observations. If there was an interaction between the factors, equations were fitted to isolate the substrates or soils.

The data were adjusted according to the following models: exponential increase to maximum of two parameters (1), exponential decay of two parameters (2) and logistic of three parameters (3):

$$
\begin{gathered}
y=a *\left(1-\exp \left(-b^{*} x\right)\right) \\
y=a^{*} \exp \left(-b^{*} x\right)
\end{gathered}
$$

where $\mathrm{y}$ is the dependent variable, $\mathrm{x}$ is the herbicide dose, $\mathrm{a}$ is the maximum value found of the dependent variable, $b$ is the rate of increase or decrease of the variable in relation to fomesafen dose;

$$
y=c /\left(1+(x / e)^{d}\right.
$$

\section{Results and Discussion}

\subsection{Studies 1 and 2}

For the variable fomesafen efficacy on E. heterophylla control, determined at 21 DAA, there was a significant interaction between all the factors of the first (substrate, herbicide and surfactant) and second studies (soil, herbicide and surfactant). For the variable SDM in Study 1 , there where no interactions among the factors tested and only the herbicide factor was significant, already in the Study 2 there was significance for soil $\mathrm{x}$ herbicide and herbicide $\mathrm{x}$ surfactant interactions.

At the soil proportion of $100 \%$ and fomesafen dose of $500 \mathrm{~g} \mathrm{ha}^{-1}$, the best weed control (Figure 1A) was attained when the herbicide was associated with surfactant at 0.2 and $1 \%$, with control levels of 55-62\%. This result was superior than the observed for the herbicide alone (32\%). Likewise, in the proportion 33\% soil (Figure 1C) the surfactants increased the efficacy of fomesafen at the highest dose. When the substrate had 100\% sand (Figure 1D), the 
highest difference in herbicide efficacy was observed for fomesafen, at $125 \mathrm{~g} \mathrm{ha}^{-1}$, in association with surfactant at $1 \%$. This treatment resulted in $57 \%$ control of E. heterophylla, which was $30 \%$ higher than the data observed with the other two treatments at this herbicide dose.
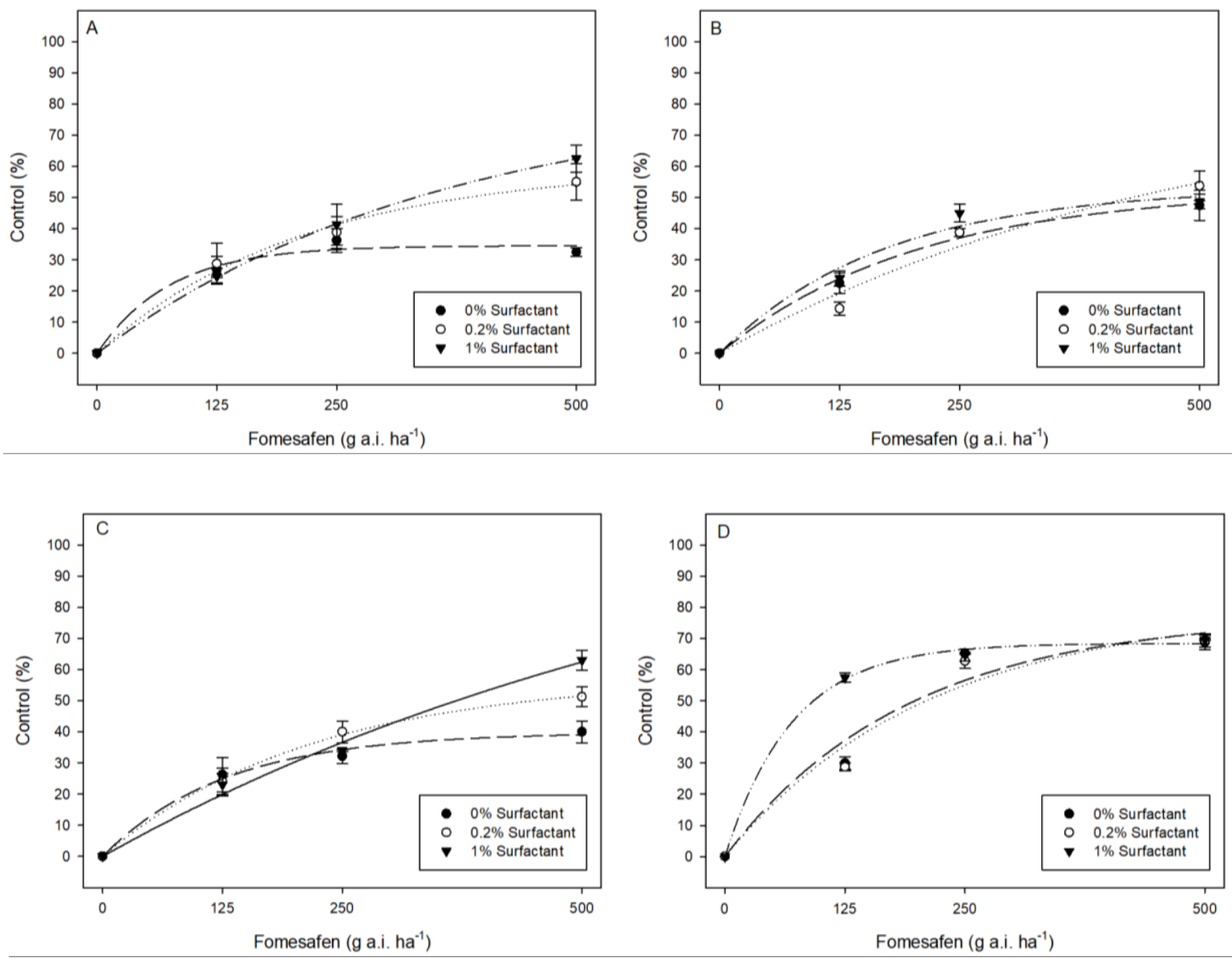

Figure 1. Control of E heterophylla (\%) at 21 days after application, in different substrates submitted at association of fomesafen and surfactant. Substrates (proportions soil/sand): A $100 \%$ soil, B $-66 \%$ soil, C $-33 \%$ soil, D - 0\% soil. Surfactant concentrations: $0 \%$ (long dash), $0.2 \%$ (dotted) and $1 \%$ (dash and dot). The bars represent the mean standard error

It should be emphasized that treatments at highest fomesafen dose presented control levels of $70 \%$. When the substrate had $66 \%$ soil on its composition (Figure 1B), overall, the association of surfactants to fomesafen did not affect the performance of the herbicide, with $54 \%$ efficacy at the highest dose. In fact, E. heterophylla SDM reduced exponentially with the increment of fomesafen doses (Figure 2). 


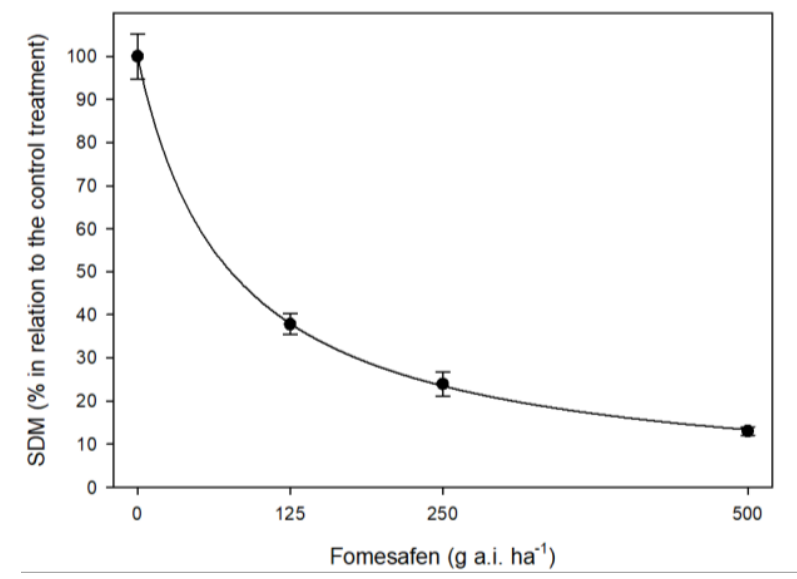

Figure 2. Shoot dry matter (SDM) in relation to the control treatment (\%) of E. heterophylla in response to the fomesafen doses. The bars represent the mean standard error

In many treatments of Study 2 (Figure 3), fomesafen, when sprayed alone, resulted in lower levels of control, compared to treatments in which the herbicide was associated to the surfactant. On the different soils, fomesafen efficacy, sprayed at the highest dose, ranged from 34 until $90 \%$.

In the soils from Pato Branco and Palmas, the association of surfactant resulted in a more expressive fomesafen response at the lowest dose (125 $\mathrm{g} \mathrm{ha}^{-1}$ ) (Figure 3A and 3C). In these soils, the higher concentration of surfactant $(1 \%)$ resulted in higher levels of weed control. It the soil from Palmas (Figure 3C), fomesafen, at the lowest dose, associated to surfactant at $1 \%$, provided $71 \%$ weed control, whereas at the maximum dose tested there resulted in $78 \%$ control. In soil from Irati (Figure 3B), the surfactant affected the efficacy of fomesafen only when sprayed at $250 \mathrm{~g} \mathrm{ha}^{-1}$.
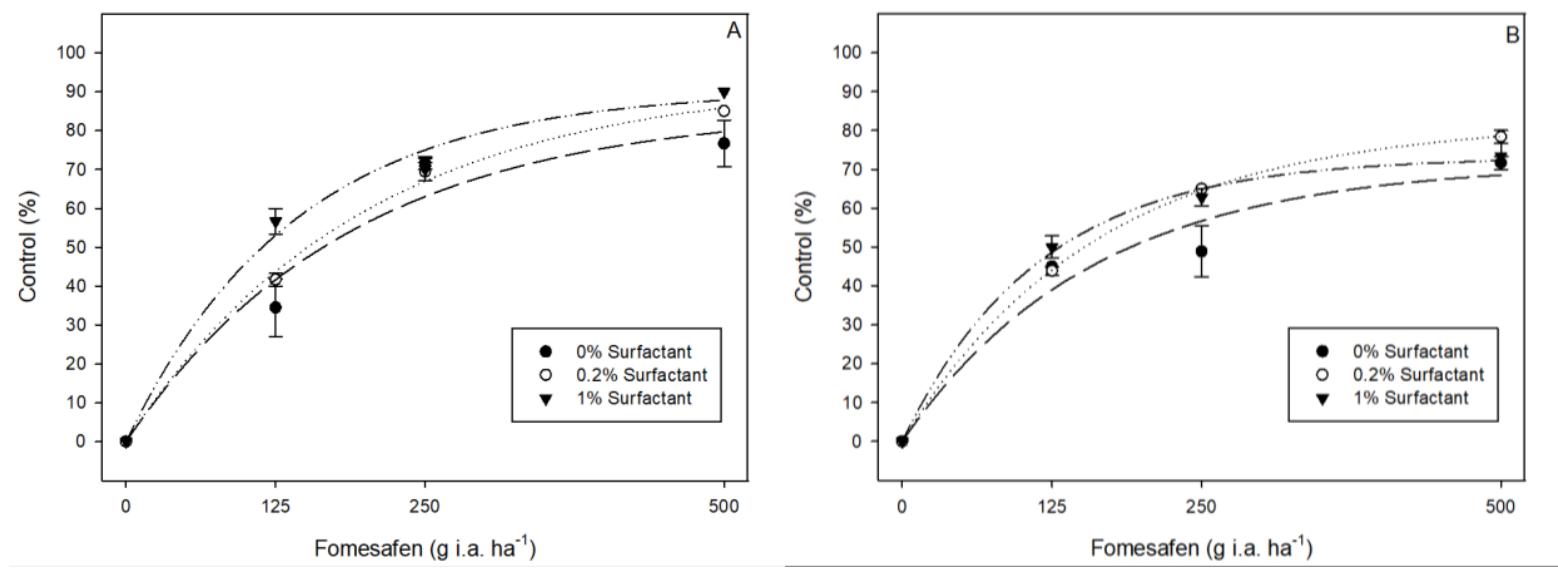


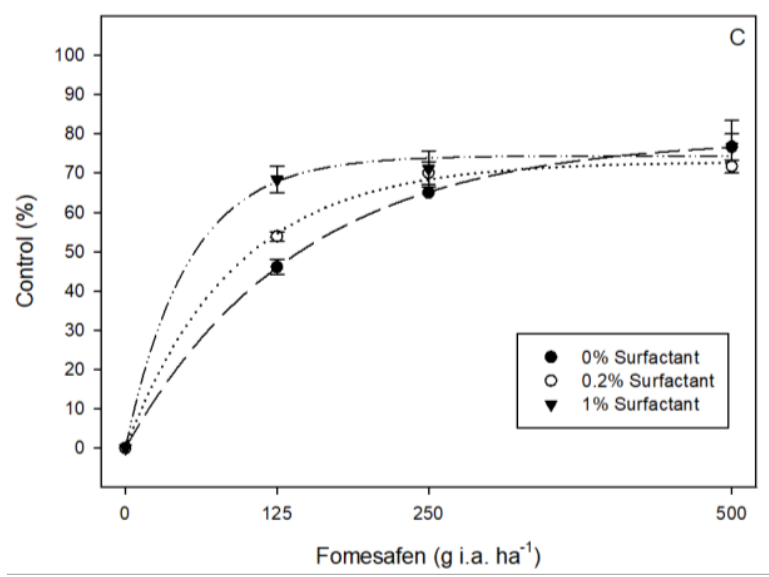

Figure 3. Control of E heterophylla (\%) at 21 days after application, in different soils submitted at association of fomesafen and surfactant. Soils: A - Pato Branco, B - Irati and C - Palmas. Surfactant concentrations: 0\% (long dash), 0.2\% (dotted) and 1\% (dash and dot).

The bars represent the mean standard error

For the SDM variable, the effect of the different soils (Figure 4A) or different surfactant concentrations (Figure 4B) was detected only with fomesafen, at a dose of $125 \mathrm{~g} \mathrm{ha}^{-1}$. When the plants were grown on the soil from Irati, fomesafen, at the dose of $125 \mathrm{~g} \mathrm{ha}^{-1}$, reduced 83\% E. heterophylla SDM (Figure 4A), whereas on soils from Palmas and Pato Branco, the SDM reductions were $94 \%$. Fomesafen at $125 \mathrm{~g} \mathrm{ha}^{-1}$, sprayed alone reduced SDM by $81 \%$ (Figure 4B), whereas the herbicide associated to $0.2 \%$ and $1 \%$ surfactant reduced SDM by $95 \%$.
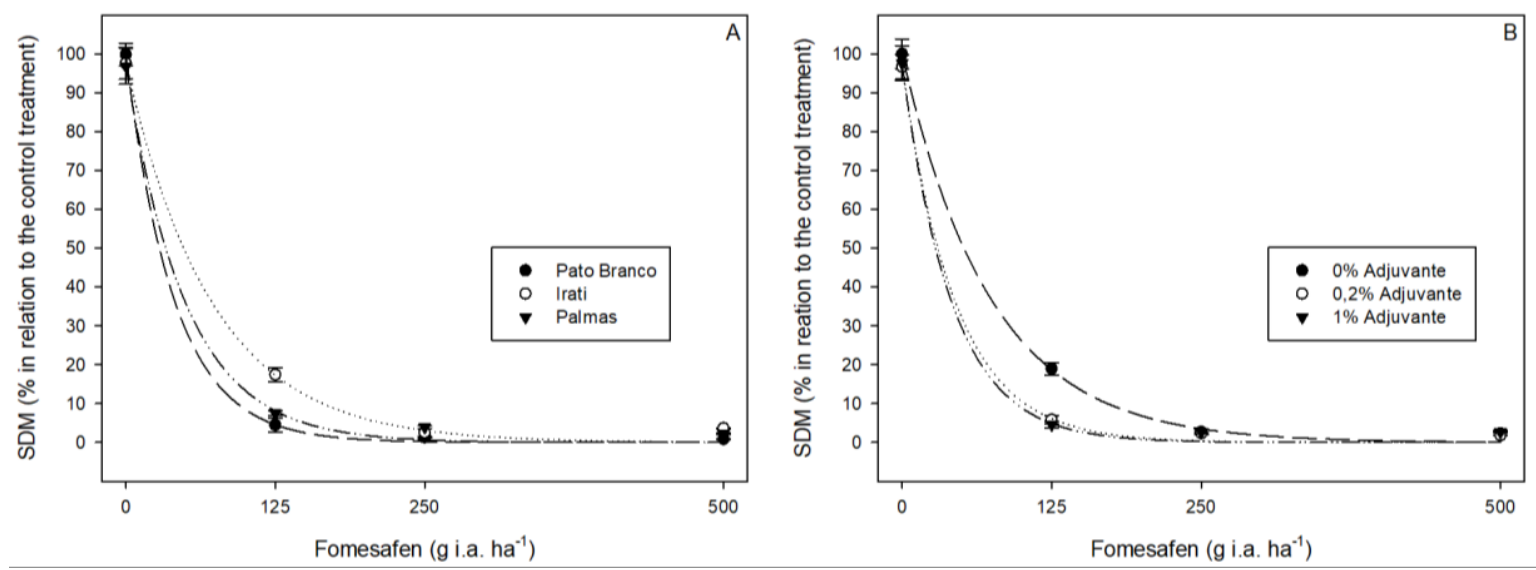

Figure 4. Shoot dry matter in relation to the control treatment (\%) of E. heterophylla in different soils (A) surfactant concentrations (B) in response to the fomesafen doses. Soils: Pato Branco (long dash), Irati (dotted) and Palmas (dash and dot). Surfactant concentrations: $0 \%$ (long dash), $0.2 \%$ (dotted) and 1\% (dash and dot). The bars represent the mean standard error

The effect of surfactant on herbicide efficacy on E. heterophylla control occurred only in certain fomesafen doses (Figures 1 and 3) and was influenced both by the soil/sand proportion and by the soil type. Overall, the highest levels of E. heterophylla control were 
observed in substrate contained only sand (no soil) (Figure 1D). It's important to note that the lowest soil organic matter (SOM) content occurred with the substrate with sand only (no soil), contrasted to the other sand proportions (Table 1). Higher levels of weed control and $E$. heterophylla shoot dry matter reduction occurred in the pots with soil from Palmas (Figure $3 \mathrm{C}$, Figure 4A). In these two conditions, best effect was observed for surfactant, at $1 \%$ concentration, associated to fomesafen, at $125 \mathrm{~g} \mathrm{ha}^{-1}$. Again, the soil from Palmas is the one with the lowest SOM content (Table 2). Therefore, it is possible to deduce that under lower organic matter levels, the addition of surfactant increases the availability of fomesafen, when at low dose, reflecting optimized E. heterophylla control. With substrate containing $100 \%$ soil, the effect of the surfactant was observed only when it was associated with the highest fomesafen dose (Figure 1A). The higher organic matter content could have been determinant for surfactant to have expressed its effect only in the higher fomesafen dose.

There is a linear adsorption of fomesafen in the soil organic matter (Senseman, 2007). Therefore, the organic matter content of the substrates may interfere in the adsorptive capacity of fomesafen, impacting its availability to E. heterophylla plant absorption. In fact, the sorption of fomesafen in Brazilian soils (Alfisol, Inceptsol and Histosol) was affected maily by organic matter content and clay type (Silva et al., 2013). Another study (Karpinski et al., 2014) indicated that the sandy loam soil had a higher phytotoxic potential of fomesafen in pre-emergence for cotton in relation clay soil.

Based on the idea that lower organic matter results in lower adsorptive capacity, it is expected that soils with higher organic matter content will have higher fomesafen sorption, reducing the herbicide availability in soil solution. This would explain the lower herbicide efficacy and decreased SDM reduction in Irati soil, compared to soils from Pato Branco and Palmas.

There are several factors that explain the influence of surfactants on herbicides action in the soil. Both adjuvants and herbicides undergo the adsorption process and, therefore, their action can be influenced by soil characteristics. For instance, there are positive correlation between surfactant adsorption and organic matter and clay content (Cano \& Dorn, 1996). The surfactant and the herbicide chemical properties may affect their mobility in the soil (Hua et al., 2009). For instance, the sorption of cyanazyne and atrazine by the soil is increased by nonanionic surfactants, however, the sorption of norflurazon is reduced by these adjuvants (Locke et al., 2002).

Increasing the amount of soil organic carbon and clay minerals reduced the impact of surfactant on herbicide desorption (Locke et al. 2002). Indeed, in the second study, Irati soil has the highest organic matter content, which would explain the limited effect of the surfactants. Furthermore, in substrate with soil/sand with higher organic matter content, the effect of surfactant only occurred at higher fomesafen doses, which is in agreement with the results reported by Locke et al. (2002). If surfactant sorption behavior resembles that of herbicide fomesafen, in substrates/soils with low organic matter/clay, both would be less adsorbed to the soil colloids, resulting in increased availability and herbicide efficacy.

The herbicide sorption to soil is reduced by its own binding to the surfactant molecule (Amonette \& O'Connor, 1980). The binding between herbicide and surfactant molecules may 


\section{Macrothink Institute ${ }^{T M}$}

influence the adsorption and degradation of active ingredient in the soil. Organic surfactants are able to solubilize organic compounds and high doses of them are able to inhibit their degradation (Laha \& Luthy, 1992) and increase herbicide residues in soil and roots (Kucharsky, 2007). Theoretically, in the association between surfactant and fomesafen, the active ingredient would be less adsorbed by the soil for a longer period of time and, also, could also be less degraded.

\subsection{Study 3}

For the variable herbicide efficacy on E. heterophylla control there was an interaction herbicide and the surfactant type, different HLB. The surfactants, when sprayed alone, were not phytotoxic. When fomesafen was sprayed at $63 \mathrm{~g} \mathrm{ha}^{-1}$, the best efficacy (80\%) was observed for the association between the herbicide and surfactants with HLB 4.3 and 8.6 (Figure 5). The other treatments at this herbicide dose ranged from 45 to $65 \%$ weed control. When fomesafen was sprayed at $125 \mathrm{~g} \mathrm{ha}^{-1}$, the best treatment (94\%) was observed for the herbicide associated to surfactant with HLB 8.6. Fomesafen associated to surfactant with HLB of 17.8 provided inferior weed control than the treatment with the herbicide alone.

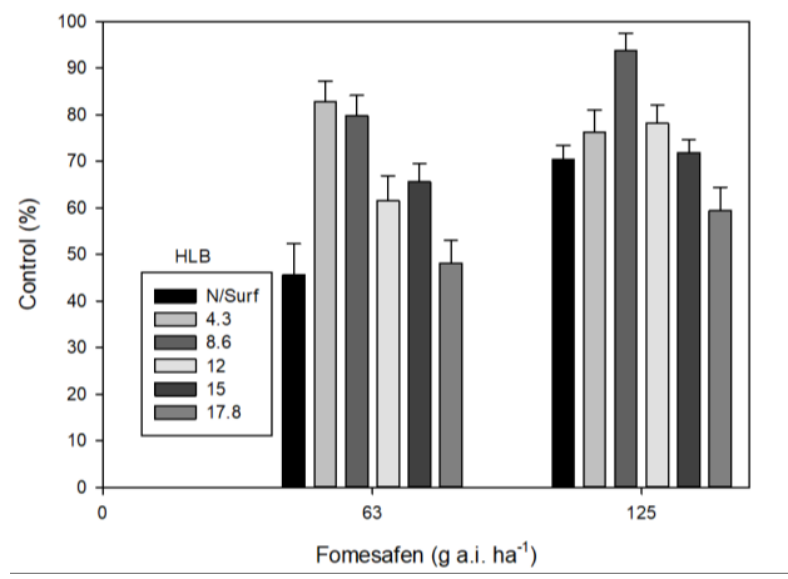

Figure 5. Control of E. heterophylla (\%) at 21 days after application in response to the association among fomesafen and surfactants with different HLB's. The bars represent the mean standard error. Observation: N/Surf $=$ No Surfactant

There were no interactions among the factors tested for SDM, and only the herbicide factor was significant (Figure 6). Fomesafen at $63 \mathrm{~g} \mathrm{ha}^{-1}$ reduced SDM by $71 \%$, whereas at $125 \mathrm{~g}$ $\mathrm{ha}^{-1}$ it reduced the SDM by $85 \%$. 


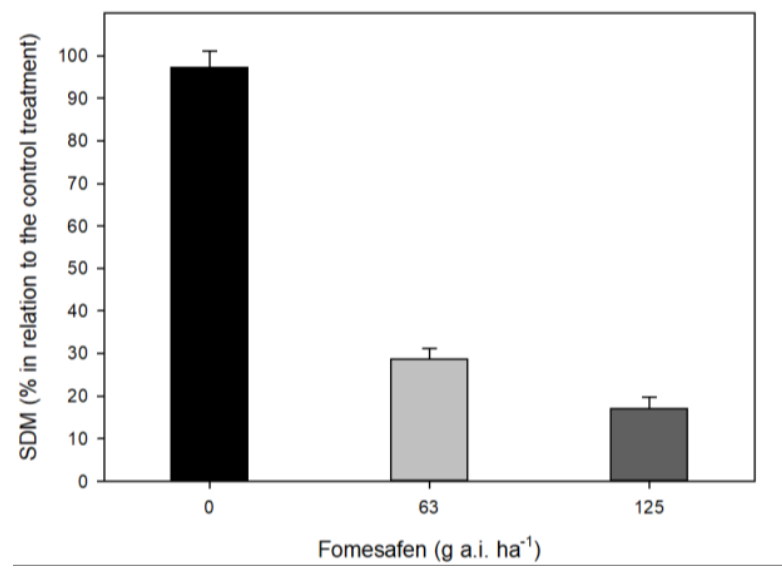

Figure 6. Shoot dry matter in relation the control treatment (\%) of E. heterophylla in response to the fomesafen doses. The bars represent the mean standard error

The fact that surfactants with HLB 4.3 (Alkest SP80) and 8.6 (Alkest L $20 \mathrm{M}$ ) increased fomesafen efficacy in relation to others surfactants (Figure 5), can be explained by their higher lipophilicity (lower HLB) among the surfactants tested. Surfactants with reduced HLB provide greater leaf absorption of herbicides with high octanol-water partition coefficient $\left(\mathrm{K}_{\mathrm{ow}}\right)$ (Green, 1999), as is the case with fomesafen ( $\mathrm{K}_{\mathrm{ow}}$ of 794 at $\left.\mathrm{pH} 1.0\right)$. Fomesafen at $63 \mathrm{~g}$ $\mathrm{ha}^{-1}$ associated with surfactant of high HLB (17.8) resulted in similar effect than the treatment without surfactant. The fact that fomesafen at $125 \mathrm{~g} \mathrm{ha}^{-1}$ associated with this surfactant (HLB 17.8) had a performance inferior than the herbicide used alone strongly suggest that there is a herbicide incompatibility with surfactant that has more hydrophilic character.

Previous studies have revealed a relationship between the surfactant HLB and the herbicide water solubility explaining the herbicide uptake (Green, 1999). A research (Amonette \& O'Connor, 1980) evaluating the effects of three non-ionic surfactants (HLB of 7.8, 10.9 and 15 ) on adsorption and degradation of 2,4-D (herbicide with high solubility in water) in two soils (clay and silty) showed that the surfactant with the lowest HLB (7.8) resulted in lower adsorption and herbicide degradation in both soils. The fact that lipophilic herbicides exert greater action when associated with surfactants with medium HLB, such as fomesafen and surfactant with HLB 8.6, can be attributed to the similarities between surfactant and herbicide. Chemicals with this attribute (similar lipophilicity) are adsorbed by organic materials via hydrogen bonding (Senseman, 2007), thus both would be adsorbed by the same binding sites of the organic matter and would degrade by the same microorganisms.

The mechanisms determining the increase in fomesafen performance with specific surfactants, with low HLB, are still unknown. Among the possibilities to be investigated are: reduced active ingredient adsorption of herbicide by herbicide-surfactant association (Hussein \& Ballah, 2016), reduced herbicide leaching (Locke et al., 2002), and decreased biodegradation (Amonette and O'Connor, 1980), allowing the herbicide to be desorbed in soil solution and over a long period of time.

Field studies testing the pre-emergence association of fomesafen and surfactants would be of great value. The experiments in the present work were carried out in a controlled environment 
are good as proof of concept, however, it is expected that variations in biotic and abiotic factors may influence the response of the herbicide-surfactant combinations. Studies that take into account these aspects would be important considering that fomesafen is not registered in pre-emergence modality for bean and soybean crops in Brazil. Also, this work demonstrated an innovative approach to increase the efficacy of herbicides on the control of E. heterophylla, among the most problematic weeds in several agroecosystems in Brazil.

The control effectiveness of E. heterophylla resistant biotype to PPO inhibitors herbicides associated with surfactants demonstrated an innovative approach to increase the efficacy in pre-emergence, in one of the most problematic weeds in several agroecosystems in Brazil. In addition, the surfactant concentrations and HLB studies evidenced that surfactant adjustment could vary weed control in pre-emergence.

For pre-emergence herbicide application, the association of surfactant and fomesafen increased the efficacy of E. heterophylla control. The hydrophilic-lipophilic balance of the surfactant influenced the performance of herbicide fomesafen in pre-emergence for $E$. heterophylla control.

\section{Acknowledgments}

For all the assistance, to the funders: Federal University of Technology - Parana (UTFPR), National Council for Scientific and Technological Development - CNPq, the Coordination of Improvement of Higher-Level Personnel - CAPES and Dr David Stock, a fellow at Syngenta's Formulation Technology Group, which examines the role of adjuvants in crop protection.

\section{References}

Amonette, J., \& O’Connor, G. A. (1980). Nonionic surfactant effects on adsorption and degradation of 2.4-D. Soil Science Society of America Journal, 44(3), 540-544. https://doi.org/10.2136/sssaj1980.03615995004400030021x

Azevedo, L. A. S. (2007). Fungicidas Sistêmicos: Teoria e Prática. Campinas: Emopi Gráfica e Editora. 284 pp.

Azevedo, L. A. S. (2011). Adjuvantes Agrícolas para a Proteção de Plantas. Rio de Janeiro: Independent production. $236 \mathrm{pp}$.

BRASIL. (2019). Sistema de Agrotóxicos fitossanitários - AGROFIT. 2019. [Online] Available: https://agrofit.agricultura.gov.br/agrofit_cons/principal_agrofit_cons. [November 05, 2019].

Brighenti, A. M., \& Oliveira, M. F. (2011). Biologia de plantas daninhas. p.1-36. In: Oliveira Jr, R.S., Constantin, J., Inoue, M.H. (Eds.), Biologia e manejo de plantas daninhas (pp. 348). Curitiba: Omnipax.

Cano, M. L., \& Dorn, P. B. (1996). Sorption of an alcohol ethoxylate surfactant to natural sediments. Environmental Toxicology and Chemistry, 15(5), 684-690. https://doi.org/10.1002/etc.5620150511 


\section{$\triangle 1$ Macrothink}

Journal of Agricultural Studies

ISSN 2166-0379

2020, Vol. 8, No. 4

Ferreira, E., Cavalcanti, P., \& Nogueira, D. (2014). ExpDes: An R Package for ANOVA and Experimental Designs. Applied Mathematics, $\quad 5, \quad$ 2952-2958. https://doi.org/10.4236/am.2014.519280

Frans, R., Talbert, R., Marx, D., \& Crowley, H. (1996). Experimental design and techniques for measuring and analysing plant responses to weed control practices. p. 29-46. In: (Camper, N. D. (Ed.), Research Methods in Weed Science (pp. 29-46). Champaign: Southern Weed Science Society.

Green, J. (1999). Effect of nonylphenol ethoxylation on the biological activity of three herbicides with different water solubilities. Weed Technology, 13(4), 840-842. https://doi.org/10.1017/S0890037X00042329

Hoagland, D. R., \& Arnon, D. I. (1950). The water culture method for growing plants without soil. Circular 347. California Agricultural Experiment Station, Berkeley, United States of America, $32 \mathrm{pp}$.

Hua, R., Spliid, N. H., Heinrichson, K., \& Laursen, B. (2009). Influence of surfactants on the leaching of bentazone in a sandy loam soil. Pesticide Management Science, 65(8), 857-61. https://doi.org/10.1002/ps.1763

Hussein, K., \& Mohamed, B. (2016). Effect of dissolved surfactants on sorption and desorption of oxyfluorfen onto prepared activated carbon. Egyptian Scientific Journal of Pesticides, 2(4), 8-16.

Karpinski, R. A. K., Oliveira Neto, A. M., Guerra, N., Constantin, J., Oliveira, Jr R. S., Maciel, C. D. G., \& Silva, A. A. P. (2014). Influence of soil texture in the selectivity of the herbicide fomesafen applied in cotton pre-emergence [Influência da textura do solo na seletividade do herbicida fomesafen aplicado em pré-emergência do algodoeiro]. Revista Brasileira de Herbicidas, 13(2), 125-133. https://doi.org/10.7824/rbh.v13i2.283

Kucharski, M. (2007). Impact of adjuvants on: phenmedipham, desmedipham and ethofumesate residues in soil and plant. Pestycydy, 3(1), 53-59. ISSN 0208-8703

Laha, S., \& Luthy, R. G. (1992). Effects of nonionic surfactants on the solubilization and mineralization of phenanthrene in soil-water systems. Biotechnology and Bioengineering, 40(11), 1367-1380. https://doi.org/10.1002/bit.260401111

Locke, M. A., Reddy, K. N., Gaston, L. A., \& Zablotowicz, R. M. (2002). Adjuvant modification of herbicide interactions in aqueous soil suspensions. Soil Science, 167(7), 444-452. https://doi.org/10.1097/00010694-200207000-00003

Senseman, S. A. (2007). Herbicide handbook. (9th ed.) Lawrence: Weed Science Society of America. p. 458.

Silva, G. R., D’Antonino, L., Faustino, L. A., Silva, A. A., Ferreira, F. A., \& Teixeira, C. C. (2013). Sorption of fomesafen in brazilian soils. Planta Daninha, 31(4), 971-977. https://doi.org/10.1590/S0100-83582013000400023 


\section{Macrothink}

Trezzi, M. M., Vidal, R. A., Kruse, N. D., Silva, R. P., Gustmann, M. S., \& Franchin, E. (2009). Site of absorption of fomesafen as a resistance mechanism in Euphorbia heterophylla biotype resistant to PROTOX inhibitors [Local de absorção de fomesafen como mecanismo de resistência em biótipo de Euphorbia heterophylla resistente aos inibidores da PROTOX]. Planta daninha, 27(1), 139-148. https://doi.org/10.1590/S0100-83582009000100018

Trezzi, M. M., Vidal, R. A., Kruse, N. D., Gustman, M. S., Xavier, E., Rosin, D., \& Dedordi, G. F. (2011). Eletrolite leakage as a technique to diagnose Euphorbia heterophylla biotypes resistant to PPO-inhibitors herbicides. Planta Daninha, 29(3), 655-662. https://doi.org/10.1590/S0100-83582011000300020

Voll, E., Gazziero, D. L. P., Brighenti, A. A. M., \& Adegas, F. S. (2002). Relative competition of weed species with two soybean cultivars [Competição relativa de espécies de plantas daninhas com dois cultivares de soja]. Planta Daninha, 20(1), 17-24. https://doi.org/10.1590/S0100-83582002000100003

Werkheiser, W. O., \& Anderson, S. (1996). Organic chemicals in the environment. Journal of Environmental Quality, 25, 809-14.

Xavier, E., Oliveira, M. C., Trezzi, M. M., Vidal, R. A., Diesel, F., Pagnoncelli, F. D., \& Scalcon, E. (2013). Acetolactate synthase activity in Euphorbia heterophylla resistant to ALS- and protox- inhibiting herbicides. Planta Daninha, 31(4), 867-874. https://doi.org/10.1590/S0100-83582013000400013

\section{Copyright Disclaimer}

Copyright for this article is retained by the author(s), with first publication rights granted to the journal.

This is an open-access article distributed under the terms and conditions of the Creative Commons Attribution license (http://creativecommons.org/licenses/by/4.0/). 